\title{
JUDICIAL MISCONDUCT AND HOW FOUR STATES DEAL WITH IT*
}

\author{
WILIIAM T. BRAITHWAITE†
}

On June Ir, r969, Sherman Skolnick, chairman of the Citizens' Committee To Clean Up The Courts, filed a motion in the Illinois Supreme Court asking the court to investigate the integrity of its decision in People v. Isaacs. ${ }^{1}$ The motion charged Chief Justice Roy J. Solfisburg Jr. and Justice Ray I. Klingbiel with "undue influence and appearance of impropriety" regarding the Isaacs decision and alleged specifically that Justice Klingbiel had received a gift of one hundred shares of bank stock from the defendant while the case was pending before the court. Both justices had voted with the 4-2 majority to affirm the trial court's dismissal of an indictment against Isaacs, and Klingbiel wrote the opinion.

Since June 1964 the power to remove Illinois judges for misconduct has been in the Illinois Courts Commission, an agency consisting of five judges, which at the time of Skolnick's motion was not permanently in session but was convened by the Supreme Court on a case-by-case basis. ${ }^{2}$ In a public statement a week after the motion was filed, the court described its dilemma in trying to decide whether to convene the Commission to investigate the allegations of misconduct against Chief Justice Solfisburg and Justice Klingbiel:

Of paramount importance was the fact that the confidence of the bar and the public in the integrity of this Court not be further impaired. It seemed to the Court that an investigation by the Illinois Courts Commission might be viewed with some skepticism. The investigating agency for that Commission is the Administrative Director of the Illinois Courts, who is appointed by, and subject to the directions of this Court, a circumstance which might raise questions.

Secondly, . . . Mr. Justice Klingbiel is presently and has been for several years, chairman of the Commission. While another member of this Court could have replaced Mr. Justice Klingbiel, this would not eliminate the problem arising from the fact that a member of this Court-a colleague of those as to whose conduct questions have been raised-was chairing the investigating body. This, again, seemed likely to be viewed with some skepticism, particularly when considered with the fact that this Court also appoints the two circuit judges who serve on the Commission.

- The research on which this article is based was supported by the American Bar Foundation but the article is entirely the responsibility of the author.

+B.A. I $96 \mathrm{I}$, Virginia Military Institute; J.D. 1964 , Washington and Lee University; Research Attorney, American Bar Foundation.

${ }^{1} 37$ Ill. 2d 205, 226 N.E.2d 38 (1967).

'Shortly after Skolnick's motion was filed, ILx. Sur. Cr. R. 5I (Smith-Hurd 1969), which governs the procedure of the Commission, was amended to provide that the Commission would be convened on a permanent basis. 
The course of action the court chose was appointment of an ad hoc group of five lawyers formally designated "The Special Commission in Relation to No. 39797" (docket number of the Isaacs case). The court gave the special commission plenary procedural powers and directed it to file its report by August $x, \mathrm{I} 969$. After extensive preliminary investigation, the commission held six days of public hearings in July during which it took testimony from twenty-one witnesses, including Chief Justice Solfisburg, Justice Klingbiel, and Theodore Isaacs, all of whom were represented by counsel.

In its report to the court, ${ }^{3}$ the special commission found that both judges had had business dealings with Isaacs while his case was pending before the court. The commission found the judges guilty not only of conduct creating a "substantial and pervasive" appearance of impropriety but also of "certain positive acts of impropriety" (emphasis in original). The commission concluded that "the confidence of the public and the Bar in the Court ... has been severely shaken by the facts disclosed in this record" and suggested the judges resign. ${ }^{4}$

It is uncertain what could have been done if the judges had refused this suggestion. The court's public statement that an investigation by the Illinois Courts Commission would be "viewed with some skepticism" was surely accurate, and the decision to appoint an ad hoc group of lawyers was therefore probably the best if indeed not the only course available, as far as finding the facts was concerned. But that is all the special commission was authorized to do: the only agency that is constitutionally empowered actually to remove a judge is the Courts Commission, which the Supreme Court had disqualified. Fortunately, on August 2, I 969 , two days after the special commission submitted its report, both judges did resign.

Fortunately, too, the Solfisburg-Klingbiel controversy is not the typical case of judicial misconduct. For one thing, cases in which termination of a judge's service is warranted are few; for another, such cases occur on appellate courts only infrequently. The more usual problems are less dramatic-habitual tardiness, short hours, long vacations, undignified courtroom behavior, arbitrary use of court powers, and extreme rudeness to lawyers, litigants, and witnesses. Examples:

-The judge who at a conference in chambers told a lawyer who refused to stipulate the amount of property damages in a tort case, "I'm going to screw you every way I can short of reversible error."

-The judge who questioned two Puerto Ricans charged with assault and robbery just long enough to learn they could not understand English, then without further ado sentenced both to ninety days in jail.

-The judge who after a cab driver charged with drunk driving testified he

\footnotetext{
${ }^{8}$ Report of the Special Commission of the Supresie Court of Illinois in the Matter of tite Special Commission in Relation to No. 39797 (People of the State of Ilinois, Appeliant v. Theodore J. Isacs, et al., Appellee) (July 3I, I969).

'Id. at 5I-53, 6I.
} 
stopped at a barbecue stand just before the accident entertained the courtroom with a knowing smirk and the question, "Did you have the strong sauce?"

-The judge who told a plaintiff's lawyer: "Mr. _ _ just understand this: I don't want to hear the reasons for objections. If I need your reasons I will ask for them. Your objection is overruled on every conceivable ground available to you."

-The probate judge who appointed his wife as appraiser of an estate in his court.

-The judge who in the midst of a busy trial season left for two weeks vacation in Florida without telling his administrative judge.

Although the fact situation in the Solfisburg-Klingbiel controversy was unusual, the policy question it presented is common to every case of judicial misconduct and central to discussion of how to deal with the problem: who has or should have the authority to regulate judicial behavior? Or, to put the analytically precedent question, what is the reason for regulating judicial behavior? It is the thesis here that the principal policy objective of a procedure for dealing with judicial misconduct as such-as distinguished from a procedure for dealing with the effects of the misconduct on the judgment in a particular case (which seems to me clearly the responsibility of the appellate process) -is to insure society's confidence in the formal system of dispute-resolution.

Broadly speaking, there are only two places to put the power to deal with judicial misconduct, either in the judiciary itself or outside it, i.e., in the legislature or the executive. A basic difficulty with putting the power in the judiciary is the political fact stated forthrightly by the Illinois Supreme Court's Justice Schaefer in Cusack $v$. Howlett, decided a few months after the Solfisburg-Klingbiel matter: "There is a latent distrust of the ability or willingness of the group of men who at any moment constitute one branch of government so to order the affairs of that branch as to satisfy legitimate public concern." On the other hand, putting the power outside the judiciary presents, as Justice Schaefer also pointed out, "the perennial problem of the independence of the judiciary from legislative or executive domination."

The principal traditional procedures-impeachment, address, and concurrent resolution-put the removal power in the legislature. ${ }^{7}$ Evidence on the effectiveness and

\footnotetext{
${ }^{5} 44$ III. 2 d 233, 一, 254 N.E.2d 506, 509 (I969).

044 Ill. $2 \mathrm{~d}$ at,- 254 N.E.2d at 508 .

"Impeachment, which exists in 46 states and the federal system, is a legislative proceeding in which the lower house acts as grand jury and the upper house as trial court. Address (28 states) is a formal request from the legislature to the governor asking him to remove a judge. Concurrent resolution is a variant form of address; if a certain percentage of both legislative houses votes to request that the governor remove a judge, he is legally obliged to do so. Another traditional procedure, recall, exists in only seven states. It is analogous to initiative and referendum; if a certain percentage of the voters sign a petition to recall a judge, he must face a special election. These procedures are further described, and constitutional and statutory citations to the law in all American jurisdictions are provided, in AM. JUD. Soc'y, Judiciar. Discipline aNd ReMroval (Report No. 5, August 1969).
} 
use of these procedures is scant, but the evidence available indicates they have been little used. ${ }^{8}$ The research on which this paper is based, though not exhaustive, found only five states that have used impeachment against judges within the last fifteen years, ${ }^{9}$ and no instance of the use of address, concurrent resolution, or recall (which exists in only seven states) within the last three decades.

Impeachment is the best-known and most widely available of the traditional procedures; it exists in forty-six states and the federal system. The main criticisms of impeachment have been that it is procedurally cumbersome and susceptible to partisan political influences. Since the forum of decision is the legislature and legislators are partisan advocates by civic obligation and practical necessity, the latter criticism seems justified. The charge of procedural cumbersomeness, however, is not borne out by the experience of Missouri, one of the five states included in the research upon which this article is based ${ }^{10}$ and one of the few states that has used impeachment in recent years. ${ }^{11}$

In March $\mathrm{rg63}$, five days before his scheduled impeachment trial on seventeen articles of misconduct, St. Louis County Circuit Court Judge Virgil A. Poelker resigned. Most of the charges were based upon the judge's tangled financial dealings; he apparently had over-extended himself and then got into a cycle of borrowing from one creditor to pay another. Although Judge Poelker's misconduct began coming to light in the spring of Ig6r, evidence sufficient to impeach him was not available until later that year, by which time the Missouri legislature was no longer in session. In January 1963 , when the legislature met again for its regular biennial session, it promptly initiated impeachment proceedings.

Another judge of the same court, John D. Hasler, resigned in August 1968, three day's before his scheduled impeachment trial on misconduct charges arising from his personal involvement with a woman divorce defendant in his court. He had previously been convicted by a jury of official misconduct (a misdemeanor) as a result of the same circumstances.

Insofar as it implies that impeachment intrinsically cannot operate expeditiously, the criticism that impeachment is procedurally clumsy is not borne out by the Poelker and Hasler cases. In both cases the proceedings, once begun, went forward

\footnotetext{
${ }^{8}$ See, e.g., Shartel, Retirement and Removal of Judges, 20 J. Am. Jud. Soc'r I33, 151 n.86 (1936), reporting two judges removed by impeachment and three by address in the period 1900-25; Miller, Discipline of Judges, 50 MrH. L. REv. 737 (1952), reporting three impeachments of judges-and all three judges acquitted-in the period r928-48; and Brand, The Discipline of Judges, 46 A.B.A.J. 1315 n.2 ( $\mathrm{x} 960)$, reporting I9 removals and three resignations as a result of impeachment proceedings "as far back as can be recalled or determined" in 40 of 45 states surveyed.

${ }^{9}$ Alabama, Florida, Missouri, Oklahoma, and Tennessee.

${ }^{10}$ Besides conventional legal materials, the research sources included public and private records and interviews with trial lawyers, judges, court administrative personnel, newspaper reporters, and others in a position to have direct knowledge of the problem. Five states were studied: Missouri, New Jersey, New York, California, and Illinois.

11 Both the Missouri impeachments referred to here are described in detail in Braithwaite, Removal and Retirement of Judges in Missouri: A Field Study, I968 WAsk. U.L.Q. 378.
} 
with reasonable dispatch. In the Poelker matter, about two and a half months elapsed between the House's adoption of a resolution initiating an investigation and the date of the impeachment trial. In Hasler's case, slightly less than six months elapsed between the initial House resolution and the impeachment trial date; by comparison, the criminal proceedings took about four months.

Missouri's experience has been that the most serious deficiency of impeachment is not procedural clumsiness but the cost of the proceedings- $\$ 64,000$ for Poelker, $\$ 20,000$ for Hasler-and the extraordinary political pressure required to trigger the procedure initially. In the Poelker case, the extent of the judge's loose financial dealings and other misconduct, a state-wide sense of outrage resulting from widespread publicity about the case, the eighteen-month delay before action to remove him could finally be taken (because the legislature was not in session), and his refusal to resign all combined to create intense pressure on the legislature to act when it convened in January 1963 for its biennial session. In the Hasler matter, the nature of the judge's misconduct was the principal factor producing the same kind of pressure, although the reaction time was considerably shortened-not surprisingly, in view of the still recent memory of the Poelker controversy, which the newspapers naturally revived.

Whatever the reason that impeachment and the other traditional procedures have fallen into disuse (it seems fair to infer that at least some states think the traditional procedures ineffective), they are today being superseded by one or the other of several "modern" procedures. Between 1960 and I970, over twenty-five states adopted by constitutional amendment, legislation, or court rule new procedures to deal with judicial misconduct. By comparison with the traditional procedures, the most notable feature the modern procedures have in common is that they put the power of final decision in the judiciary itself, either in the state supreme court or in a court constituted specially to hear and decide cases of judicial misconduct.

The prototype of the first arrangement is the procedure of California's Commission on Judicial Qualifications; of the second, the procedure of New York's Court on the Judiciary. The California Commission is a nine-member agency (five judges, two lawyers, two laymen) with its own independent staff; it is authorized to receive and investigate complaints, hold confidential fact-finding hearings, and recommend appropriate action to the state supreme court, which alone has the power actually to remove or censure a judge. The New York Court consists of six judges but exists permanently only on paper, the members for a particular case being appointed on an ad hoc basis. Unlike the California procedure, the New York Court has no hearing agency and no permanent staff of its own.

Both the California and the New York prototypes have been copied in other states, the former in twelve, the latter in five. ${ }^{12}$ There are also variations of both

\footnotetext{
${ }^{12}$ Depending upon which features of a particular procedure are taken as its defining characteristics, an estimate of the number of states that have adopted that procedure will vary. The estimates here are
} 
prototypes. In New Jersey, for example, as in California, it is the state supreme court that has the power actually to remove or discipline a judge. But the New Jersey procedure does not include a separate hearing agency; instead, on an ad hoc basis, the court sometimes appoints a single judge as master or referee to hold in camera hearings, find the facts, and report to the court. ${ }^{12 a}$ Nor does the New Jersey procedure include an independent staff; the state court administrator serves this function.

The Illinois Courts Commission resembles the New York Court on the Judiciary in that it is a court specially constituted to decide cases of judicial misconduct. ${ }^{13}$ Another similarity is that both agencies lack a hearing agency. Unlike the New York Court, however, the Illinois Commission does have a staff-the state court administrator, as in New Jersey.

The research on which this paper is based included a detailed study of the removal-discipline procedures in these four states-New Jersey, New York, California, and Illinois. The immediate objective was to learn how some of the principal modern procedures actually operate. A more general objective was to identify the functional similarities and differences among procedures, with a view to suggesting which features recommend themselves for imitation and which for eschewal.

\section{II}

In the past fifteen years, the New Jersey Supreme Court has dealt in formal, reported disciplinary proceedings with eight cases of judicial misconduct. At least that many more cases during the same period have been handled informally and off the record. The reported cases include ticket-fixing, ${ }^{14}$ income tax evasion, ${ }^{15}$ violation of court rules limiting the practice of law by lawyer-magistrates, ${ }^{16}$ and violation of customs and court rules relating to maintenance of order and decorum in the courtroom. ${ }^{17}$ Among the incidents handled informally are drinking, submitting false statistical reports on court workload, practicing law while a judge, and habitually failing to follow prescribed procedures in handling criminal cases. ${ }^{17 a}$

based principally upon who has the decision-making power-the state supreme court or a specially constituted court. See generally Report No. 5, supra note 7, at n.7.

${ }^{12 a}$ Under the procedure prescribed by a statute approved and effective July 24, 1970, cvidence in judicial removal-discipline proceedings may be taken either before the Supreme Court en banc or before three judges designated by the Chief Justice. N.J. Laws I970, ch. I5I.

${ }^{13}$ The Illinois Courts Commission is an example of the confusing names some removal-discipline agencies have. Though called a "commission," the Illinois agency is in fact a court, since it has power to make a final decision and render a judgment on the merits, that is, to remove or discipline a judge. California's Commission on Judicial Qualifications, by contrast, does not have such powers.

${ }^{16}$ In re Orsini, 37 N.J. 500, 18r A.2d 77 I (1962).

${ }^{28}$ In re Gurnik, 45 N.J. I15, 211 A.2d 777 (I965).

${ }^{16}$ In re Klaisz, Ig N.J. I45, Ix5 A.2d 537 (1955); In te Palmisano, I8 N.J. 497, Ix4 A.2d 553 (I955).

${ }^{17}$ In re Stevens, 20 N.J. II7, II9 A.2d 9 (1955).

${ }^{172}$ Since the research for this article was completed, there have been the following recent incidents of judicial misconduct in New Jersey. Passaic County Court Judge Stanley Polack, upon being convicted of income tax evasion, resigned from the bench. Union County District Court Judge Ralph De Vita, upon being convicted of obstructing justice, resigned from the bench and the bar. Newark Municipal Court Chief Magistrate James Del Mauro resigned after disciplinary proceedings were initiated against him on 
The New Jersey Supreme Court's authority to deal with judicial misconduct has evolved principally from its constitutionally assigned "jurisdiction over admission to the practice of law and the discipline of persons admitted."18 Pursuant to this power the court has made the Canons of Professional Ethics and the Canons of Judicial Ethics legally binding on lawyers and judges in New Jersey. ${ }^{19}$ And in a Ig6r decision, In re Mattera, ${ }^{20}$ the court construed its power to discipline members of the bar to extend to lawyers in judicial office.

The court's ability to deal with judicial misconduct is facilitated by its plenary power in the area of administration. By constitutional provision, the court is directed to "make rules governing the administration of all courts."21 The extent and diversity of the court's administrative rules make evident that it exercises this power with vigor and decision. ${ }^{22}$ The constitution also makes the Chief Justice "administrative head of all the courts" and gives him authority to "appoint an Administrative Director to serve at his pleasure."23 The statute prescribing the Administrative Director's functions is both specific and comprehensive. ${ }^{24}$ In addition to his statutorily prescribed duties, the Administrative Director is also the staff for the Supreme Court in its capacity as removal-discipline agency.

The New Jersey Supreme Court's authority to administer the court system and discipline lawyers and judges originated in 1947 with the adoption of the present constitution. The judicial article of this constitution completely reorganized the state's court system, which until then had remained basically unchanged since I844. It was a system with a hundred years' accretion of antique habits and legislative patches, characterized by a labyrinthine court structure and an utter absence of administrative direction and authority. ${ }^{25}$

It was the intention of the drafters of the new judicial article that judicial misconduct be dealt with directly by the Supreme Court. The article provided that "The Judges of the Superior Court and the Judges of the County Courts shall also [in addition to being subject to impeachment] be subject to removal from office by the Supreme Court for such causes and in such manner as shall be provided by

the grounds he violated a Supreme Court directive forbidding acceptance of fees or gratuities for performing marriages. Letter from New Jersey Supreme Court Chief Justice Joseph Weintraub to Robert W. Meserve, Sept. 16, I970 (quoted with permission).

${ }^{18}$ N.J. Consr. art. VI, $\$ 2,93$.

${ }^{10}$ N.J. Sup. Cr. R. $x: 14$.

${ }^{20} 34$ N.J. 259,168 A.2d 38 (196r).

21 N.J. ConsT. art. VI, $\S 2$, I 3 .

39 See generally N.J. Sup. CT. R. pt. I, ch. IV ("Administration"); McConnell, The Administrative Office of the Courts of New Jersey, I4 Rutgers L. Rev. 290 (I960).

${ }^{23}$ N.J. Const. art. VI, $\S 7$, I 1 .

${ }^{24}$ N.J. Rev. StAT. 2A:12-3 (1965).

${ }^{35}$ Some discussion of New Jersey's old (pre-I947) court system and the reform movement leading to its abolition and replacement by the present system can be found in Evans, Constitutional Court Reform in New Jersey, 7 U. Newark L. Rev. I (I94I); Harrison, New Jersey's New Court System, 2 Rutgers L. Rev. 60 (r948); Hartshorne, Progress in New Jersey Judicial Administration, 3 RuTGers L. Rev. r6r (I949); and Milmed, The New Jersey Constitution of 1947, N.J. STat. ANN. (Const. vol.) at xiii (West 1954). 
law."2B More than two decades elapsed, however, before the legislature finally, in April 1970, adopted a statute implementing this grant of power to the Supreme Court.

Whatever the reason for the legislative delay, it left the Supreme Court, until adoption of the 1970 statute, with the responsibility but not the power to deal with judicial misconduct. One solution to this dilemma lay in a careful reading of the judicial article provision requiring implementing legislation. While it was clear that without legislation the court could not remove a judge, nothing forbade the court actively to encourage a misbehaving judge to remove himself, that is, to resign or retire. Confronted with substantiated reports of a judge's heavy drinking, Chief Justice Vanderbilt personally suggested to the judge that he ought to retire. The judge did. Anoher case, involving falsification of statistical reports of court workload, was handled the same way, with a similar result.

In the twenty-year period ending in 1968 , at least eight incidents of serious judicial misconduct have been handled in this manner by either Vanderbilt or his successor, the present Chief Justice. Not all resulted in the judges' termination of service, however. In several cases, the judge has been disciplined by reprimand or admonition in a private hearing before the Supreme Court en banc or, occasionally, the Chief Justice alone. All these proceedings have been off the record.

Some other cases have resulted in reported court decisions, the first of which occurred in $1955,{ }^{27}$ eight years after the new judicial article became effective. Then, in 196r, the court decided In re Mattera, holding that the court's constitutionally assigned disciplinary power over persons admitted to the bar extended to lawyers in judicial office, and thus by implication holding also that disbarment or similar discipline could be imposed upon a judge. The theory of the court's decision was this:

In terms of rational connection with fitness at the bar, behavior of an attorney in judicial office cannot be insulated from the demands of professional ethics. On the contrary, the judge's role is so intimate a part of the process of justice that misbehavior as a judge must inevitably reflect upon qualification for membership at the bar..$^{28}$

The procedural pattern for the court's handling of judicial misconduct cases is now well established. ${ }^{29}$ Complaints are received, screened, and preliminarily investigated by the Administrative Director of the Courts. If his report substantiates the allegations, the court orders the respondent judge to show cause why he should not be held in contempt, disbarred, or otherwise disciplined. Depending upon the nature and complexity of the case, the court may hear argument on the show-cause order

\footnotetext{
${ }^{20}$ N.J. Const. art. VI, $\$ 6$, ף 4 (emphasis added).

${ }^{27}$ In re Palmisano, I8 N.J. 497, II4 A.2d 553 (I955); In re Klaisz, I9 N.J. I45, I15 A.2d 537 (1955); In re Stevens, 20 N.J. I77, II9 A.2d 9 (1955).

${ }_{28} 34$ N.J. $259,264,168$ A.2d 38, 4 I (I96I).

${ }^{20}$ Reported cases decided subsequent to Mattera are In re Orsini, 37 N.J. 500, I81 A.2d 771 (1962); In re Pagliughi, 39 N.J. 517, I89 A.2d 218 (1963); In re Hayden, 4r N.J. 443, I97 A.2d 353 (r964); In re Gurnik, 45 N.J. 115, 21 A.2d 777 (1965).
} 
without further proceedings, or it may, as it did in Mattera, appoint a judge to make formal fact-findings and a report before it hears argument. Throughout, both sides are represented by counsel, the court appointing a lawyer on an ad hoc basis to prosecute the case, occasionally someone from the state attorney general's office. ${ }^{29 a}$

The procedure in those cases handled off the record is similar, except that it is sometimes less formal. The Administrative Office is still the investigative agency, but all proceedings are confidential and any hearing is in camera before the court en banc or, occasionally, the Chief Justice alone. If the court decides that the misconduct warrants termination of the judge's service, it asks him to resign or retire, and the case is closed when he does so. The option of a full-dress adversary proceeding is open to a judge who wishes to contest the allegations against him.

\section{III}

While New York has a battery of removal procedures-five in all ${ }^{30}$-only the best-known will be discussed here. That is the Court on the Judiciary, prototype of those modern procedures in which power to remove is put in a specially constituted court rather than in the state supreme court.

Created by constitutional amendment adopted in 1947, the Court on the Judiciary is empowered to remove "for cause" any judge of the five major trial courts or the Court of Appeals, which is the highest appellate court. ${ }^{31}$ The six members of the Court on the Judiciary are the Chief Judge and senior associate judge of the Court of Appeals and one judge from the Appellate Division in each of the four "departments" into which the state is divided for court administration purposes (the Appellate Division is New York's intermediate appellate court).

The Court's powers-to summon witnesses, take evidence, and so on-and the respondent's rights-notice, opportunity to be heard, and so on-are the usual ones. But the procedure for setting the Court in motion is somewhat curious, as is the provision which allows legislative pre-emption of removal proceedings once they are begun. The Court is not a continuing body but is convened on a case-by-case basis by the Chief Judge of the Court of Appeals. He may act on his own motion, but he is required to convene the Court upon the written request of the governor,

\footnotetext{
306 "The Attorney General or his representative shall prosecute the proceedings unless the Supreme Court shall specially designate an attorney for that purpose." N.J. Laws $x 970$, ch. 15I.

${ }^{80}$ Impeachment, N.Y. CoNsr. art. VI, $\$ 25$, has existed in New York since I777 and has been used once, in 1872 (judge removed), 4 C. Lincoln, Constitutionat History of NEW York 605 (I906). Removal by concurrent resolution of the two houses of the legislature, N.Y. ConsT. art. VI, $\$ 23 a$, has never been used. The procedure whereby a judge can be removed "for cause" by two-thirds vote of the senate upon recommendation of the governor has been used four times, once in 1866 (judge acquitted), twice in 1872 (one judge removed, the other acquitted), and most recently in 1939 (judge acquitted), 4 Lincoln, supra, at 585. The Appellate Division, which is the intermediate appellate court, is authorized to remove judges of lower courts. N.Y. Consr. art. VI, $\$ 22 \mathrm{i}$. This procedure is described in detail in my forthcoming monograph on removal and retirement of judges.

${ }^{31}$ N.Y. Const. art. VI, $\$ 22$. The five major trial courts are the Supreme Court, which has state-wide general jurisdiction, and four courts with state-wide limited jurisdiction: the Court of Claims, Surrogate's Court, County Court, and Family Court.
} 
any one of the four Presiding Justices of the Appellate Division, or a majority of the executive committee of the state bar association.

Once charges are preferred, regardless who initiates the convening, the Chief Judge, as "presiding officer" of the Court, is required, before hearing, to give written notice of the judge's name, the nature of the charges, and the hearing date to the Governor, President of the Senate, and Speaker of the Assembly. If any member of the legislature prefers the same charges against the judge within thirty days of this notice and "such charges are entertained by a majority vote of the assembly, proceedings before the court on the judiciary shall be stayed pending the determination of the legislature, which shall be exclusive and final."32

The Court has been convened three times since $1947^{33}$ The first case involved two Brooklyn judges, Nathan R. Sobel and Samuel S. Leibowitz, who used the press as a forum for statements critical of each other's official conduct in connection with a much-publicized murder trial. Judge Sobel made a statement implying that Judge Leibowitz had knowingly participated in the prosecution of an innocent fifteen-yearold boy; Judge Leibowitz responded that Judge Sobel should "keep his filthy mouth shut." Two weeks after the exchange of statements, the Chief Judge of the Court of Appeals appointed two judges as a committee to investigate the incident. As a result of the committee's report, the State Judicial Conference adopted a resolution finding that the two judges had "abused their public offices" and "rebuked and reprimanded" them.

After receiving a copy of the resolution and a transcript of the testimony taken by the investigating committee, the Chief Judge convened the Court on the Judiciary. At its first meeting, the Court adopted procedural rules and appointed two lawyers to conduct the proceedings. The charges prepared by the lawyers alleged that the judges' statements "violated the concept, spirit and letter of the canons of judicial .ethics," offended "judicial decorum and propriety," and brought "into disrepute the administration of justice in Kings County."

Both judges' counsel moved to dismiss the proceedings on the grounds that the charges did not as a matter of law constitute "cause" for removal. In a brief per curiam opinion announced July 8, I960, the Court held that the charges were legally sufficient (and denied the motions to dismiss) but also that the facts in the case did not justify removal. Although the opinion did not explicitly censure the judges, it was strongly condemnatory of their actions. ${ }^{34}$

\footnotetext{
${ }^{82}$ N.Y. Const. art. VI, $\S 22 \mathrm{~b}$.

83 The following accounts of the Court on the Judiciary's three cases are based entirely upon official records in the custody of the Clerk of the New York Court of Appeals.

s4 'The court said in part: "We hold that the conduct of each respondent was wrongful. Judge Sobel's fault was in making ill-considered and unfounded accusations or suggestions that a criminal case had been unfairly prosecuted. Judge Leibowitz offended against judicial decorum and dignity by using a courtroom as a forum for vilification of a fellow jurist. ... Such personal altercations among Judges are indefensible. It is a disservice to the courts .... It is an affront to the State and its citizens. The public had a right to be indignant at such a display ...." In re Sobel, In re Leibowitz, 8 N.Y.2d at (a) (Court on the Judiciary $x 960$ ).
} 
The Court was convened for the second time a little more than two years later. Second Department Appellate Division Presiding Justice George J. Beldock requested that the Court be convened to consider the conduct of Judge Louis L. Friedman in refusing to produce certain records subpoenaed in an investigation of Brooklyn lawyers' solicitation of personal-injury lawsuits.

The rules adopted by the Court in the Friedman case were identical to those adopted in the Sobel-Leibowitz controversy except that Rule I was amended to provide that four members rather than five would constitute a quorum. The charges served by the two lawyers appointed to conduct the proceedings alleged that Judge Friedman had "abused his public office" in three particulars: (I) by interfering with and obstructing the investigation; (2) by maintaining exclusive possession of the records of his former law partnership with his brother Malcolm and refusing to account to Malcolm for the records; (3) by failing to observe the "concept, spirit and letter of the canons of judicial ethics."

After motions and other preliminary proceedings, the Court heard final oral argument, then, on February 26, I963, two members dissenting, announced its decision finding Judge Friedman guilty of the charges and removing him from office. ${ }^{35}$

The Court on the Judiciary's third case involved Judge Melvin H. Osterman of the Court of Claims. In April Ig63, Judge Osterman voluntarily appeared before a New York County (Manhattan) grand jury investigating an alleged conspiracy to bribe an official of the State Liquor Authority. At the hearing, Chief Assistant District Attorney Alfred J. Scotti asked Judge Osterman to sign a general waiver of immunity from subsequent criminal prosecution. The judge refused to sign a general waiver but offered Scotti an already signed waiver limited to matters involving performance of his official judicial duties. Scotti declined to accept the limited waiver, and the judge was excused and did not testify.

Subsequently, in response to a request from the governor, the Court on the Judiciary was convened. The preliminary proceedings followed the pattern established in the Sobel-Leibowitz and Friedman matters: adoption of rules; appointment of a clerk; designation of counsel to conduct the proceedings; preparation of charges by counsel; and a preliminary determination by the Court that the charges were legally sufficient.

Initially, four charges were brought against Judge Osterman, ${ }^{36}$ the principal one being that he refused to co-operate with the grand jury by refusing to sign a general waiver of immunity. The judge's answer admitted that he had refused to

\footnotetext{
${ }^{55}$ In re Friedman, 12 N.Y.2d at (a) (Court on the Judiciary $196_{3}$ ), motion to vacate judgment denied, id. at (e), appeal dismissed for lack of jurisdiction, I9 App. Div. 2d I20, 24x N.Y.S.2d 793 (3d Dept. 1963), appeal dismissed for want of a substantial federal question sub nom. Friedman v. Court on the Judiciary, 375 U.S. ro ( 1963 ).

${ }^{30}$ The charges alleged that Judge Osterman (I) had practiced law since becoming a judge by advising certain persons in their dealings with the State Liquor Authority (SLA); (2) falsely denied to Chief Assistant District Attorney Scotti that he had practiced law since becoming a judge; (3) refused to co-operate with the grand jury investigation of the SLA by not signing a general waiver of immunity; and (4) had attempted to obstruct the investigation by hiding a typevriter of evidentiary value.
} 
sign a general waiver, and the lawyer designated to conduct the proceedings thereupon moved for judgment of removal on this ground alone. In granting the motion, the Court said:

Public officers including judges may claim all the rights available to other citizens, including the right to claim immunity and to refuse to waive it. It does not follow, however, that a judge after successfully asserting such a right may claim another right to remain in judicial office.... "Cause" for removal of a Judge may be found not only in official misconduct but in his taking attitudes and positions which show unfitness for the office and unworthiness of the trust. Such unfitness and unworthiness is demonstrated by a refusal by a Judge sworn to enforce law to co-operate in any investigation of official corruption. ${ }^{37}$

\section{IV}

California's removal-discipline mechanism is the prototype of the so-called "commission" procedure. The decision agency is the state Supreme Court, which may remove or censure a judge for willful misconduct, willful and persistent failure to perform his duties, habitual intemperance, or "conduct prejudicial to the administration of justice that brings the judicial office into disrepute."38

In practice very few cases actually reach the court. Nearly all are resolved by the Commission on Judicial Qualifications, a hearing agency authorized to receive and investigate complaints, hold hearings and make findings of fact, and recommend to the court that the court remove or censure a judge.

In its first nine years of operation ( $196 \mathrm{r}-69$ ), the Commission received on average one hundred complaints a year, of which about two-thirds usually were unfounded or outside Commission jurisdiction. During this nine-year period, fifty judges resigned or retired during Commission investigation of their performance or conduct (many of these terminations of service were the consequence of disability rather than misconduct, however ${ }^{39}$ ).

The members of the Commission are five judges appointed by the Supreme Court, two lawyers appointed by the state bar, and two lay citizens appointed by the Governor with Senate approval. The Commission meets regularly about once every two months, occasionally more often if necessary. A full-time Executive Secretary, assisted by an office secretary, is responsible for day-to-day administrative operations and the receiving, screening, and investigation of complaints. The Executive Secretary does most of the investigative work himself but sometimes employs outside investigators; in a few major cases, the investigation has been done by the Bureau

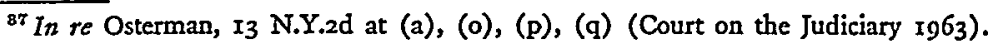

${ }^{88}$ CaL. Const. art. VI, $\S \pm 8$.

${ }^{89}$ The Commission is also the hearing agency in disability cases. Because Commission proceedings and records are confidential by law, it is not known how many of the fifty terminations of service were for misconduct and how many were for disability. Based upon the findings of research in other states about the comparative incidence of these two types of problems, I surmise that between $50 \%$ and $75 \%$ of the total terminations in California were a consequence of disability.
} 
of Criminal Investigation and Intelligence, an agency of the California Department of Justice.

Complaints come from various sources-litigants, lawyers, judges, public officials, and bar associations. Overall, most complaints come from litigants, although the actionable complaints come mostly from lawyers and judges. Litigants' complaints are very often an attempt to use the Commission as a means to appeal an adverse judgment. Such complaints, along with others that are prima facie frivolous or unfounded, are acknowledged by the Executive Secretary with a letter explaining why the Commission cannot act and are marked "Closed by Staff" without further action. All complaints (including those closed by staff) and pending cases are reviewed by the full Commission at its regular meetings.

Complaints that are prima facie valid are investigated by the Executive Secretary. Although the Commission's procedural rules seem to require that a judge who is the subject of a prima facie valid complaint be notified once an investigation begins, ${ }^{40}$ the Commission does not in practice give such notice until it determines through informal inquiry that a prima facie valid complaint does indeed have some factual basis.

What approach the Commission takes once it determines a complaint has a factual basis depends upon the case. Initially it may simply write the judge a letter saying that an apparently valid complaint against him is on the Commission's agenda and is being investigated. In cases of minor misconduct, such as tardiness or discourtesy, where the facts are not complicated and the Executive Secretary's informal inquiry is conclusive, the Commission often writes a "Staff Inquiry Letter" informally stating the charges and requesting the judge's explanation. If the explanation is satisfactory, the case is closed. Occasionally, closing the case is expressly conditioned upon the cessation of certain conduct. Or the Commission may write the judge a letter of admonition or reprimand. Sometimes, as the Executive Secretary has put it, "there may be reason to accept the plea, 'I didn't do it but I'll see it doesn't happen again'."4I

The judge's reply, or perhaps failure to reply, may show the need for further investigation. In cases of serious misconduct and cases where a "Staff Inquiry Letter" has not produced sufficient improvement in the judge's behavior, the investigation sometimes leads to a formal fact-finding hearing. If as a result of the hearing the Commission finds "good cause" 42 to do so, it recommends to the Supreme Court the censure or removal of the judge.

Until such a recommendation is made, all proceedings are confidential by law, a policy designed to encourage judges who are conscious of guilt to resign or retire voluntarily before the proceedings become public by virtue of a Commission recommendation for court action. In most cases where termination of service is warranted, the judge resigns or retires fairly early in the proceedings, often even without a formal

\footnotetext{
${ }^{10}$ CaL. R. Cr. g04 (West I970).

"I Frankel, The Case for Judicial Disciplinary Measures, 49 J. AM. JUD. Soc'y 2r8, 221 (I966).

${ }^{2}$ CaL. R. CT. 917 (West 1970).
} 
hearing. As the Commission's Executive Secretary has pointed out: "If there is proof of a situation serious enough to justify full proceedings, the significance and gravity will often be apparent to the judge and his counsel and he may resign or retire."

In only two cases since rg6r has the Commission had a full proceeding and made a recommendation to the Supreme Court. The Commission recommended in February I964 that Judge Charles F. Stevens be removed for willful misconduct. In its report accompanying the recommendation, the Commission found the judge guilty of showing bias against the prosecution in criminal cases by dismissing cases for trivial reasons and ridiculing and belittling law enforcement officers and other public officers appearing for the prosecution. The Commission also found that the judge had been evasive and untruthful in his testimony at the hearing, had once dismissed a criminal case in which he appeared as the defendant's lawyer before becoming a judge, and had allowed lawyers to practice before him who owed him money and were representing him in a lawsuit. In a brief per curiam opinion, the Supreme Court rejected the Commission's recommendation that Judge Stevens be removed. ${ }^{44}$

In June I970, pursuant to Commission recommendation, the court censured Judge Gerald S. Chargin ${ }^{45}$ for statements made by him at a juvenile hearing involving a fifteen-year-old Mexican-American boy charged with incest. The Commission's report found that the judge's statements were "insulting to the minor's family, offensive to large segments of the public, and ... [indicated] feelings and attitudes of ethnic bias."

Several thoughtful constitutional provisions supplement the Commission's operations. On the theory that one whose fitness for judicial office has been brought seriously into question should not sit in judgment of others, California has provided that a judge indicted for a felony or recommended by the Commission for removal is automatically disqualified from acting in his official capacity. ${ }^{46}$ If an indicted judge is convicted, the Supreme Court may suspend him; if the conviction becomes final, the court must remove him. ${ }^{47}$ It is also provided that a judge removed from office is thereafter ineligible for judicial office and is automatically suspended from practicing law, pending further order of the court. ${ }^{48}$

\footnotetext{
${ }^{\star s}$ Frankel, Judicial Discipline and Removal-The California Plan, 58 IL.. B.J. 510 (1970).

"Why the court rejected the Commission recommendation is not clear. Both the Exccutive Secretary and the now retired appellate judge who was chairman of the Commission at the time have publicly speculated that the court may have felt Judge Stevens deserved discipline rather than removal but did not think it had this power. (Stevens was decided two years before the 1966 constitutional amendment giving the Supreme Court power to censure as well as remove. Compare CaL. Const. art. VI, \$ Iob (r960) suith id. § 18). See Frankel, Judicial Discipline and Removal, 44 TExAs L. Rev. Ir17, I129 (1966); Bray, Judging Judges-The California Commission on Judicial Qualifications, 33 NEv. S.B.J. 28, 31 (1968). See also I965 Report of the CoMmission on Judicial Qualifications to the Governor 3.

"E In re Chargin, 2 Cal. 3d 822, 471 P.2d 29 (I970), 87 Cal. Rptr. 709.

${ }^{\circ} \mathrm{CAI}$. Const. art. VI, $\$$ I8(a).

${ }^{47} I d . \$ \mathrm{I} 8(\mathrm{~b})$.

${ }^{4} I d . \S \mathrm{I} 8(\mathrm{~d})$.
} 
In external appearance, the Illinois Courts Commission resembles the New York Court on the Judiciary. Both are courts constituted specially to try cases of judicial misconduct. Unlike the "special court" procedure, however, the Illinois Commission has a permanent staff and agency continuity (the New York Court's members are appointed on a case-by-case basis), which are characteristic features of those procedures modeled after California's Commission on Judicial Qualifications.

The Illinois Commission was created by constitutional amendment adopted in November Ig62 to take effect January I, Ig64. The amendment provided:

[S]ubject to rules of procedure to be established by the Supreme Court and after notice and hearing, any judge may be retired for disability or suspended without pay or removed for cause by a commission composed of one judge of the Supreme Court selected by that court, two judges of the Appellate Court selected by that Court, and two circuit judges selected by the Supreme Court.99

Pursuant to this authority the Supreme Court promulgated in May 1964 its Rule 5I, establishing the Illinois Courts Commission and prescribing a procedure for the Commission to receive, investigate, and hear complaints of judicial misconduct (and disability).

The first request to convene the Commission arose from an incident in September I964 involving Judge Wayne W. Olson of the Circuit Court of Cook County. Judge Olson had been bound over to the grand jury on a charge of involuntary manslaughter as a result of the death of Lawrence Benner, who died from a skull fracture apparently caused by his head hitting the sidewalk during some sort of scuffle that occurred outside a restaurant-cocktail lounge where he and Judge Olson had been in conversation. When the case reached the grand jury in January 1965 , the jury voted no indictment; Chief Judge John S. Boyle thereupon requested the Supreme Court to convene the Commission. Ten days later, the court announced it would not do so, even though it did not "consider the conduct of Wayne W. Olson on the evening in question appropriate to the position of a judge." The court cited insufficient evidence and the grand jury's failure to indict as the basis of its decision.

The Olson case made it manifest that the Commission itself had no practical existence except at the pleasure of the Supreme Court. Under Rule $5^{\mathrm{x}}$ as originally adopted in May Ig64 and existing at the time of the Olson case, the Commission did not sit permanently; rather, it was to be called into existence- "convened" in the words of the rule-only when the Supreme Court found there was reason to do so. ${ }^{50}$ Clearly this arrangement gave the Commission itself no real power.

In late I966, when the Supreme Court Rules Committee was finishing a complete

${ }^{\circ}$ ILL. Const. art. VI, $\S \mathrm{r} 8$.

${ }^{50}$ The relevant part of the rule provided that complaints would be submitted to the Administrative Office of the Illinois Courts. Then: "If the Supreme Court determines there is reason to convene the commission, or upon request of the Senate, the Chief Justice shall order the commission to convene." 29 Ill. 2d at xv (I964) (emphasis added). 
revision of the court's rules, a suggestion was made that Rule $5^{1}$ be amended to provide that the Commission would sit on a permanent basis. The court refused this suggestion. When the revised rules became effective January I, I967, Rule 5I with minor language changes, remained identical in substance to its predecessor.

The Commission was actually convened for the first time three years after it was established. The case began when a Chicago judge, Louis W. Kizas, released on their own recognizance two men charged with robbing a Catholic church. Release on a recognizance (no-cash) bond for a criminal suspect charged with a felony involving the use of a weapon-the robbers shot at a nun-is very unusual in Chicago. When Chief Judge Boyle learned of the suspects' release, he decided to investigate Judge Kizas' bond-writing practices further.

As a result of the investigation and pursuant to Chief Judge Boyle's request, the Supreme Court convened the Commission May 18 , 1967. The burden of the complaint filed against Judge Kizas by the Attorney General a month later was that the judge had "illegally taken and received sums of money for and in consideration of his performance of official duties" and that he had "displayed total disregard for the rules of the Circuit Court of Cook County [regarding setting bonds]." October 2 was set as the date for the Commission en banc to hear evidence on the merits. On September I4, Judge Kizas, citing poor health, resigned. ${ }^{51}$

A second judge, James E. Murphy, was also charged with misconduct as a result of Chief Judge Boyle's investigation of Chicago judges' bond-writing practices. At a public hearing June 3 , Ig68, the Commission heard evidence on the charges against Judge Murphy; a week later, it announced its decision finding the judge not guilty of misconduct and dismissing the complaint. ${ }^{52}$

A month after Judge Kizas' resignation, the Illinois State and Chicago Bar Associations established the Joint Committee on the Illinois Courts Commission "to study and made recommendations for the more effective use" of the Commission. A year and seven meetings later, the committee petitioned the Supreme Court to make certain amendments in Rule 5 , which the court did, on June 27 , 1969. The most important change was that the Commission was convened on a permanent basis. The Director of the Administrative Office of the Illinois Courts was made "permanent Secretary" for the Commission and given the duty to receive and investigate complaints; he was also authorized to make investigations on his own motion and to hire investigators to assist him.

\footnotetext{
${ }^{81}$ This account of the case is based upon the official record, In re Kizas, M.R. II74 (Ill. Cts. Comm'n I964). Two years after his resignation, Kizas pleaded guilty to criminal charges of official misconduct and was fined \$15,000, People v. Kizas, No. 68-2734 (Cir. Ct. Cook County, Ill., Crim. Div., decided Aug. 5, 1969). Three months later, on his own motion, his name was stricken from the roll of attorneys, In re Kizas, Gen. No. 42503 (Ill. Sup. Ct., decided Nov. 25, 1969).

${ }^{52}$ In re Murphy, M.R. II77 (Ill. Cts. Comm'n 1968). The principal charges against Judge Murphy were that he set 702 bonds in a twenty-one month period; that he set bonds at places other than his regularly assigned place of duty and at times when bonds would normally have been issued by specifically designated courts; and that he set bonds in amounts higher than prescribed by court rule. Judge Murphy was not charged, as Judge Kizas was, with accepting money to set bail.
} 


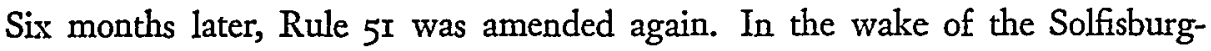
Klingbiel case (see Part I), the Supreme Court in September 1969 appointed a committee to draft a new code of judicial ethics and another committee to write rules of procedure for hearings before the Commission. The procedural amendments to Rule $5^{I}$ were effective January $I, I 970 ;{ }^{53}$ the new code of ethics was adopted a month later as Rules $6 \mathrm{I}-7 \mathrm{I}^{54}$

Rules 6r-7x are divided into Standards of Judicial Conduct and Rules for the Regulation of Judicial Conduct. The Standards are mostly normative exhortations: A judge should ... (or should not). The Rules are mostly specific prohibitions regarding problems that have been particularly troublesome, and not only in Illinois: business activity, charitable solicitation, compensation for non-judicial services, political activity, and financial and other conflicts of interests.

It is explicitly provided that violations of the Standards and Rules will subject the offending judge to discipline by the Illinois Courts Commission, ${ }^{55}$ clearly a mandate by the court for the Commission to assume responsibility for enforcement of the new standards. Since the amendments to Rule 5 I making the Commission a permanent agency with "full judicial power and authority" as well as full procedural power, including the power to investigate and hear cases on its own motion, it has the procedural means to carry out this mandate.

Thus invigorated, the Commission began in July I969 to meet regularly each month. During the ensuing eight-month period (through the end of February r970), it received and investigated I2I complaints, fifteen of which were sufficiently meritorious to be assigned Commission docket numbers and placed on the agenda of business for further action. ${ }^{56}$ In one of these cases, which was decided July I4, I970, the Commission removed Cook County Circuit Court Judge Richard A. Napolitano. ${ }^{57}$

\section{VI}

In evaluating various removal-discipline procedures, it is necessary to remember that the general problem of judicial misconduct includes a range of particular problems, from corruption and major felonies at one extreme to tardiness and discourtesy at the other. To be effective, a procedure should be able to deal with all

\footnotetext{
${ }^{53}$ The amendments effective January I, I970, included these provisions: (a) in case of a hearing, formal charges are to be served on the judge according to the rules for service of process in civil cases; (b) the Commission is authorized to delegate to one of its members "such matters of preliminary determination as it may deem desirable;" (c) the allegations of the complaint must be proved by "clear and convincing evidence;" (d) the Commission was given the power to punish, by sanctions including contempt, "breaches of order and unprofessional conduct."

¿4 ILL. SuP. Cr. R. 6I to 7 I (Smith-Hurd I970).

${ }^{E V} I d .$, Rules 62, 7r.

- Testimony of the Honorable Roy O. Gulley, Director of the Administrative Office of the Illinois Courts and Secretary of the Illinois Courts Commission, Before the Judiciary Committee of the Illinois Constitutional Convention (Springfield, Feb. 24, 1970).

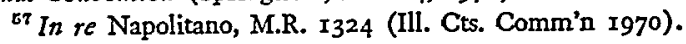


these problems; that is, it should be capable of a range of dispositions, from informal admonition $^{58}$ to formal public censure ${ }^{59}$ and termination of service. To be efficient as well, the procedure should be capable of operating reasonably expeditiously and with minimum cost and public spectacle.

This research found that most actionable complaints of judicial misconduct call for discipline rather than removal, and that in most cases where discipline is imposed, it is done confidentially (and often informally) rather than publicly. It also appears, moreover, that where the decision agency is empowered only either to remove or to acquit entirely-as in impeachment, for example-fewer complaints are made, suggesting that the unavailability of a disciplinary sanction discourages the reporting of less serious but nevertheless actionable misconduct, just those cases, in other words, that constitute the bulk of the problem.

These findings suggest that the best procedures will be those most capable of informal operation. The procedures that as a result of this research were judged to have this capability have two characteristics in common: they have staff, and they operate confidentially in preliminary proceedings.

Without staff, a removal-discipline agency has no practical existence. The staff provides agency continuity and an identifiable, conveniently accessible presence in the community; its responsibilities are to receive and screen complaints and make preliminary investigations. Maintaining confidentiality in preliminary proceedings serves several purposes. It protects judges from groundless accusations. It encourages complaints from trial lawyers, who while they are in the best position to know first-hand about some kinds of misconduct are sometimes reluctant to report it because they believe that if they do their clients' interests will suffer. In those cases where termination of service is warranted, confidentiality allows the judge to avoid the time, expense, and spectacle of a public trial by resigning or retiring, a convenient and desirable disposition from the agency's point of view also. Finally, in cases where termination of service is not warranted, confidentiality facilitates discipline, since contrition and co-operation from the judge are more likely if he is not made needlessly to suffer a public recitation of his professional or personal failings.

While staff and confidentiality are the procedural features that seem essential to effective informal operations, there is one other feature that is very helpful-a hearing agency. The hearing agency should be authorized to hold full-dress adversary hearings and its proceedings should be confidential, an arrangement with several advantages. It provides a calm atmosphere for fact-finding and the procedural protections necessary to insure the respondent judge a fair hearing; it therefore maximizes the likelihood that the judge will resign or retire if found guilty of misconduct warranting removal.

\footnotetext{
${ }^{88}$ Admonition is used, for example, in California. See Frankel, Judicial Discipline and Removal, 44 TExas L. Riv. III7, II3I (xg66).

${ }^{60}$ Formal public censure is employed, for example, in New Jersey. See In re Pagliughi, 39 N.J. $5 x 7$, I89 A.2d 218 (1963); In re Hayden, 4I N.J. 443, I97 A.2d 353 (I964).
} 
In terms of these features-staff, confidentiality, and hearing agency-the procedures in the four studied have varying profiles. The New York Court on the Judiciary does not recommend itself for imitation. Being ad hoc and without staff, the Court has no continuity and is not conveniently accessible to potential complainants; furthermore, the requirement that the Chief Judge notify the governor and legislature every time the Court is convened means that proceedings cannot be kept confidential. Together these circumstances effectually incapacitate the Court from acting informally, which explains, I think, why the Court has been convened only three times since 1947 when it was created.

The procedures in New Jersey, California, and Illinois are similar in some respects. All have staff-the state court administrator in New Jersey and Illinois, an independent executive secretary in California. In all three states, proceedings are confidential until a formal hearing before the decision agency. Functionally, too, the procedures are similar, the operational objective in all three states being to resolve actionable cases informally and confidentially if possible and to use the machinery for formal proceedings only if absolutely necessary.

California is the only one of the three states with a separate hearing agencythe Commission on Judicial Qualifications. In addition to receiving, screening, and investigating complaints, the Commission is also authorized to impose informal discipline, such as oral admonition and written reprimand. Since in California, as in the other states studied, most cases call for discipline rather than removal, the Commission, besides being the hearing agency, is as a practical matter also the decision agency in most cases.

New Jersey does not have a separate hearing agency, but the Supreme Court sometimes uses the functionally similar device of appointing, on an ad hoc basis, a judge as master or referee to take evidence, find the facts, and report to the court. ${ }^{60}$ The hearing judge is not authorized to impose discipline, however; in New Jersey, unlike California, all discipline, formal and informal, is imposed by the Supreme Court.

The Illinois Courts Commission does not have a separate hearing agency, but because the Commission has been regularly active as a permanent agency only since July 1969 it is too soon to say whether this is a serious limitation. The January I970 amendments to Illinois Supreme Court Rule 5I, which governs the Commission's procedure, included a provision that the Commission may delegate to one of its members "such matters of preliminary determination as it may deem desirable." Whether this means that one commissioner could serve as a hearing judge, to find the facts and report them to the Commission, is problematic; it would seem he might then be disqualified from sitting with the Commission en banc to rule on the merits.

The extent of the Commission's power to impose discipline confidentially is also unclear. Rule $5^{\mathrm{I}}$ has always provided that any hearing in misconduct cases "shall be

\footnotetext{
${ }^{\circ 0}$ See note 12a supra.
} 
public." Rule $7 \mathrm{r}$, however, adopted in February 1970 as part of the Standards and Rules for the Regulation of Judicial Conduct, gives the Commission power to issue reprimands "not of record." Since the imposition of discipline without a hearing raises due process issues, the Commission may soon have either to amend the public hearing requirement of Rule $5 \mathrm{I}$ or interpret it in such a way that it is consistent with both due process and the power to impose discipline confidentially.

Which procedure is best? Evaluated on the basis of those features necessary to maximize the capacity for informal disposition, the New Jersey and California procedures are equally effective. The Illinois Courts Commission, while it began inauspiciously in 1964 as a variation of the New York Court on the Judiciary, has since evolved into a procedure much superior to its prototype and having features of both the New Jersey and California procedures. 